\title{
Cost Analysis of Nursing Practice by Applying Reuse and Repack Methods on Sterile Practice Materials in the Clinical Laboratory
}

\author{
Henny Yulianita $^{1}$, Afif Amrullah ${ }^{2}$, Dyah Setyorini ${ }^{3}$ \\ ${ }^{1,3}$ Faculty of Nursing, Universitas Padjadjaran, ${ }^{2}$ Faculty of Health Science, National Development \\ Veteran Jakarta \\ Email:h.yulianita@unpad.ac.id
}

\begin{abstract}
The activity of nursing practice in the laboratory, required sterile equipment that is still wrapped neatly. Equipment had broken wrap, will be discarded. Although the equipment is still good and feasible to be reused. Reuse and repack is a method of repackaging of used sterile equipment.This method is expected to reduce the cost of practice and reduce environmental waste. This study aims to analyze the cost of nursing practice by applying reuse and repack methods on sterile practice materials. This study is a field study using observation method on the practice of urinary catheter insertion and nasogastric tube installation conducted by nursing students in the clinical laboratory. The number of students involved as many as 74 people. Instrument tool pricing standards based on online rates published by health equipment standard sites. Findings Through the application of reuse and repack methods, the cost of the practice of urinary catheter insertion can be saved by 1.6 million $(90 \%)$ and the cost of installation practice can be saved by 3.6 million (85\%) for once practice. The results of the cost analysis of nursing practice in the laboratory using reuse and repack methods on the practice of urinary catheter insertion and the practice of ngt installation can save the cost of nursing practice.
\end{abstract}

Keywords: Cost Analysis, nursing practice in laboratory, reuse and repack method. 
Henny Yulianita : Cost Analysis of Nursing Practice by Applying Reuse and Repack Methods

\section{Introduction}

Nursing is a form of service that is an integral part of the service based on nursing science and tips in the form of a comprehensive bio-psycho-socio-spiritual service aimed at individuals, families, and communities, both sick and healthy covering the entire process of life (Praptiningsih, 2006). According to Roger, nursing as a profession that combines elements of science and art. Nursing as a science is a humanistic science that studies the nature and direction of human development as a whole with the environment, whereas according to Henderson nursing is to help individuals who are sick and healthy in carrying out activities that have a contribution to health and healing individuals are able to do without help when the individual has the necessary strength, will, and knowledge (Kusnanto, 2004).

Nursing as a profession is one of the jobs where in determining his actions are based on science and have clear skills in his expertise. In addition, as the nursing profession has autonomy in authority and responsibility in actions and codes of ethics in work and services oriented to the provision of nursing care for individuals, groups and society (Hidayat, 2008). The nurse is the one who has the ability and authority to perform nursing actions based on the knowledge they have gained through nursing education (UU Kesehatan No. 23 tahun 1992 in Asmadi, 2008).

The science in question is cognitive knowledge and skills related to nursing knowledge gained through nursing education. Nursing education in Indonesia is divided into vocational and professional education. For vocacially under the auspices of the Indonesian Diploma Education Association (AIPDIKI) and the Association of Indonesian Ners Education Institutions (AIPNI). In an effort to print nursing staff, both AIPDIKI and AIPNI require a prospective nurse to meet the educational competency standards. Educational competencies that must be met include the ability to master the cognitive and psychomotor aspects of skills in performing nursing actions (Asmadi, 2008). In Indonesia, the number of nursing diploma and ners education institutions reached 655 units, not including midwifery education (Kemenkes 2014). While the number of nursing students is approximately $31 \%$ of total medical students is 261.773 people.

In skills-related nursing education there are in almost all subjects such as surgical medical nursing, nursing skills, and basic nursing science. In the course, there are skills that must be mastered and understood by the students. During a nursing student to be declared graduated from his academic education, a nursing student must master certain skills such as injecting, putting catheters, install NGT and others, obtained through nursing practice practice in the laboratory. According to Zainuddin (2005) states the usefulness of practicum in the learning process are as follows:

- Coaching skills that students need

- Provide opportunities for students to apply and integrate knowledge that has been previously possessed in practice

- Proving and/or finding a concept scientifically (scientific inquiry)

- Appreciate the knowledge and skills possessed.

Through practical learning experience, it is hoped that students can develop attitudes, behaviors, knowledge, and basic professional skills (Nursalam \& Efendi, 2008).

The practice of nursing skills training in the laboratory that must be done by nursing students reaches approximately 101 types of skills. Of these, 34 of them require consumables such as gloves, syringes, hose/ tube, plaster and others. According to the rules, to achieve the appropriate skills standards in kilinik or in the hospital, all equipment must meet the standards of practice as well, which is a tool wrapped in a neat, clean, and some of the tools to be under sterile conditions. For example, if the 34 skills require gloves multiplied by the total number of nursing students throughout Indonesia as much as 261,773 people, then the required number of gloves is estimated to reach $8,900,000$ pairs or about 180,000 boxes, which in the money reaches 3.6 billion rupiahs. Not including other equipment. This will affect the high cost of institutional operations and ultimately the cost of this education is charged to the students.

Reuse or reuse is the activity of reusing 
Henny Yulianita : Cost Analysis of Nursing Practice by Applying Reuse and Repack Methods

materials or materials that are still fit to use. For example, plastic bags or paper bags that are generally obtained from the results we shop for, should not be thrown away but collected for reuse when needed. Reuse of used goods that are still suitable for use can be done for materials or materials in the form of rubber, leather, fabrics such as used bags, used shoes, used bed linen and others. Before reuse, the item or material must be washed, disinfected and drained. The purpose of this action is to reduce the risk of exposure to infection to the material to be reused. After all processes are carried out, the goods or materials are packaged properly. Packaging can be simple or more attractive than the original packaging of the factory. In principle, this activity takes advantage of used goods by processing materials to be reusable. Benefits of reducing and reusing (EPA US, 2017):

- Prevents pollution caused by reducing the need to harvest new raw materials

- Saves energy

- Reduces greenhouse gas emissions that contribute to global climate change

- Helps sustain the environment for future generations

- Saves money

- Reduces the amount of waste that will need to be recycled or sent to landfills and incinerators

- Allows products to be used to their fullest extent

In Unpad's faculty of nursing laboratory, disposable items are partially re-used but not re-packed. So students sometimes use used materials to perform nursing actions. Although the material is still functioning properly, but not re-packing well, it is likely to affect the end result of the goal of nursing practice. The disposible material in the form of rubber and plastic that still works well, can be reused. Through the act of disinfection and repackaging, packaging is carried out simply compared to original factory packaging. This disposable material is safe to use as a material for nursing action practices.

Methods of re-pack and re-use is a wrapping method with the use of the sterile equipment used. It is expected that this method can lower the cost of practice and reduce environmental waste. Benefits of re-use methods: preventing pollution through waste reduction, energy saving, cost-effectiveness, reducing the amount of waste to be brought to the landfill, making the product usable for a long time and saving natural resources (Rose, 2017).

One example to do repacking is in RS Dr Sutomo Surabaya. In this hospital, the pharmaceutical department has made repacking efforts on drugs, where large doses of drugs and not according to individual needs, repacked, resulting in a small dose. For example, the dose is available $500 \mathrm{mg}$, while the patient's need is $400 \mathrm{mg}$. By the hospital has done repacking so that the remaining 100 $\mathrm{mg}$ tsb can be used by the patient itself or other patients who need similar drugs. The pharmacy's efforts were able to save 8 billion/ year or 615 million USD (Detik News, 2013).

The general objectives of this study are analyzing the impact of re-use and re-packing on costs incurred in nursing practice of NGT and urinary catheters. Specific objectives of the study were to

- determine the amount of costs incurred in the nursing practice of catheter installation and nasogastric tube installation prior to the re-use and re-packing method,

- to know the amount of cost spent on nursing practice of catheter installation and nasogastric tube installation after re-use and re packing,

- comparing the costs incurred for nursing practice of catheter insertion and nasogastric installation before and after the use of reuse and repacking methods.

\section{Research Method}

This study is a field study using observation method on the practice of urinary catheter insertion and nasogastric tube installation conducted by nursing students in the clinical laboratory. The number of students involved as many as 74 people. Instrument tool pricing standards based on online rates published by health equipment standard sites.

The location of research in unpad nursing faculty laboratory in the month of February - March 2018. Population and sample are all students of UNPAD nursing faculty who are conducting NGT nursing practice test and urinary catheter installation. The number of 
Henny Yulianita : Cost Analysis of Nursing Practice by Applying Reuse and Repack Methods

students per action is 74 people. Before the observation, students already know the type of equipment required, students are given inform consent, the observation is two days for the two activities.

Implementation stages:

Stage I, Criteria: Selection of materials to be done re-using method.

1. Goods are disposable equipment

2. Goods made of plastic or semi-synthetic rubber

3. Goods are still in good condition physically

4. Goods still function properly

Stage II, Repacking.

After fulfilling the criteria re-using, then the goods will be re-packing. For repacking required sealer tool, glue, plastic type mica and paper type foodgrade. If not obtained, can use LDPE plastic (low density poly ethylene). The cleaned and dried apparatus will be placed on the original packing paper, then the edges of the paper will be sintered with mica/PE (polyetilene) plastic by using white fox glue around the material. Furthermore, heating using a sealer. After that, do the label on the goods to show the name and type of goods and time for packing and expiration date.

\section{Stage III, Cost Analysis}

Observations of the types of goods that meet the criteria of repacking and re-using are discarded by the students. Next will be analyzed the amount of costs spent by respondents based on the list prices of medical equipment owned by the seller online.

\section{Research Results}

Table 1 Type of Equipment Required And Can Be Re-Used And Re-Packed On Urinary Catheter Insertion

\begin{tabular}{lclcc}
\hline \multicolumn{1}{c}{ Item spesific } & Number of item & Use status & Re-use & Re-pack \\
\hline Glove & 1 & Disposible & yes & No \\
Surgical Glove & 1 & Disposible & Yes/No & Yes \\
Catheter Tube & 1 & Disposible & Yes & Yes \\
Spuit $10 \mathrm{ml}$ & 1 & Disposible & Yes & Yes \\
Urin Bag & 1 & Disposible & Yes & Yes \\
Kassa & 2 pack & Undisposible & No & No \\
\hline
\end{tabular}

Description: not calculated for plaster, jelly, and antiseptic fluid

Table 2 Type of Equipment Required and Can Be Re-Used And Re-Packed in Nasogastric Tube Installation

\begin{tabular}{lcccc}
\hline \multicolumn{1}{c}{ Item spesific } & Number of item & Use status & Re-use & Re-pack \\
\hline Glove & 1 & Disposible & yes & No \\
NGT & 1 & Disposible & Yes & Yes \\
Spuit $10 \mathrm{ml}$ & 1 & Disposible & Yes & Yes \\
Spuit $50 \mathrm{ml}$ & 1 & Disposible & Yes & Yes \\
Kassa & 2 pack & Undisposible & No & No \\
\hline
\end{tabular}

Table 3 Analyze The Purchase Price of The Type of Equipment Required and Can Be Re-Used and Re-Packed on Urine Catheter Insertion

\begin{tabular}{lclc}
\hline \multicolumn{1}{c}{ Item Spesific } & Number of Item & Use Status & Price (rupiah) \\
\hline Glove & 1 & Disposible & 2,000 \\
Surgical Glove & 1 & Disposible & 3,000 \\
Catheter Tube & 1 & Disposible & 12,500
\end{tabular}


Henny Yulianita : Cost Analysis of Nursing Practice by Applying Reuse and Repack Methods

\begin{tabular}{cccc} 
Spuit $10 \mathrm{ml}$ & 1 & Disposible & 8,500 \\
\hline Urin Bag & 1 & Disposible & 5,500 \\
Kassa & 2 pack & Undisposible & -- \\
& Total & & 31,500 \\
\hline Reterence: alatkesenatan.Id & &
\end{tabular}

Table 4 Analyze The Purchase Price of The Typeof Equipment Required and Can Be Re-Used and Re-Packed on The Nasogastric Tube Installation

\begin{tabular}{lccc}
\hline \multicolumn{1}{c}{ Item Spesific } & Number of Item & Use Status & Price (rupiah) \\
\hline Glove & 1 & Disposible & 2,000 \\
NGT & 1 & Disposible & 20,000 \\
Spuit $10 \mathrm{ml}$ & 1 & Disposible & 8,500 \\
Spuit $50 \mathrm{ml}$ & 1 & Disposible & 20,000 \\
Kassa & 2 pack & Undisposible & - \\
& Total & & 50,500 \\
\hline
\end{tabular}

Reference: alatkesehatan.id

Table 5 Analysis of The Practice Costs That Must Be Prepared For Each Student On The Skills of Urinary Catheters And Nasogastric Tube installation.

\begin{tabular}{lc}
\hline \multicolumn{1}{c}{ Type of skills } & Total cost required for each student (Rupiah) \\
\hline Installation of urine catheter & 31,500 \\
Installation of nasogastric tube & 50,500
\end{tabular}

Thus, the amount of costs incurred for 74 students undertaking catheter urine installation and NGT installation is

Rp. 82.000,- x 74 students = Rp. 6.068.000,This fee is charged to student tuition fees. This is only the cost of 2 nursing action practices, not yet for the practice of other nursing actions. The increase in the price of disposible goods affects the increase in tuition fees of nursing students.

Cost analysis using the method of re-use and re-pack

1. Purchase equipment for the implementation of re-use and repack methods

Table 6 Type and Price of Equipment Used

\begin{tabular}{lcc}
\hline \multicolumn{1}{c}{ Type of tools } & $\begin{array}{c}\text { The costs required for each } \\
\text { student (Rupiah) }\end{array}$ & $\begin{array}{c}\text { The price of each item of } \\
\text { application }\end{array}$ \\
\hline Engine sealer & 120,000 & 100 \\
White fox glue & 20,000 & 100 \\
Food grade paper & $12,000(100$ pieces) & 120 \\
White LDPE plastic & 8,000 & $50-250$ \\
Desinfectant & 68,000 & $50-100$ \\
& & \\
Total & $\mathbf{2 2 8 , 0 0 0}$ & \\
\hline
\end{tabular}

2. Cost analysis required for each tool to implement re-use and re-packing methods 
Henny Yulianita : Cost Analysis of Nursing Practice by Applying Reuse and Repack Methods

Table 7 Details of Re-Use An Re Packing Costs Of Urinary Catheter Insertion Skills

\begin{tabular}{lccccc}
\hline Item spesific & \multicolumn{5}{c}{ Price/Unit/Rupiah } \\
\cline { 2 - 5 } & $\begin{array}{c}\text { Food grade } \\
\text { paper }\end{array}$ & LDPE plastic & Engine sealer & Desinfectant & Total \\
\hline Glove & - & - & - & 50 & 50 \\
Surgical Glove & 120 & - & 100 & 50 & 270 \\
Catheter Tube & 120 & 100 & 100 & 50 & 370 \\
Spuit $10 \mathrm{ml}$ & 120 & 50 & 100 & 50 & 320 \\
Urin Bag & 240 & 200 & 100 & 50 & 590 \\
& & Total & & & 1,600 \\
\hline
\end{tabular}

Table 8 Details of Re-Use And Re-Packing Costs of Ngt Installation Skills

\begin{tabular}{cccccc}
\hline Item spesific & \multicolumn{5}{c}{ Price/Unit/Rupiah } \\
\cline { 2 - 6 } & $\begin{array}{c}\text { Food grade } \\
\text { paper }\end{array}$ & LDPE plastic & Engine sealer & Desinfectant & Total \\
\hline Glove & - & - & - & 50 & 50 \\
NGT & 120 & 100 & 100 & 50 & 370 \\
Spuit $10 \mathrm{ml}$ & 120 & 50 & 100 & 50 & 320 \\
Spuit $50 \mathrm{ml}$ & 120 & 50 & 100 & 50 & 320 \\
& & Total & & & 1,060 \\
\hline
\end{tabular}

3. Cost comparison analysis between before and after use of re-use and re-packing methods.

Table 9 Details of Re-Use An Re Packing Costs of Urinary Catheter Insertion And Ngt Installation Skills

\begin{tabular}{lcccc}
\hline \multirow{1}{*}{ Type of skill } & \multicolumn{4}{c}{ Comparison of Costs (rupiah) } \\
\cline { 2 - 5 } & Before & After & Difference & Percentage \\
\hline Urinary Catheter & 31,500 & 1,600 & 29,900 & 94.92 \\
Insertion & & & & \\
NGT Installation & 50,500 & 1,060 & 49,440 & 97.90 \\
\hline
\end{tabular}

Type of equipment needed is:

Before the application of the reuse and repack method, the costs that must be incurred to purchase equipment and materials for the installation of a urine catheter are Rp. 31,500/student, the cost of equipment and installation materials for NGT Rp. 50,500/student. Through the application of the method of reuse and repack on the act of installing a urine catheter can save costs as much as Rp. 29,900/student, the NGT installation measures can save costs of Rp. 49,440/student.

Thus the cost that can be saved by the application of the re-use and re-pack method in the nursing practice of urinary catheter installation and the installation of NGT is an average of $96.3 \%$. This will have a positive impact on reducing the burden of student tuition fees and financing nursing practice in the nursing laboratory.

\section{Discussion}

The practice of nursing in the laboratory is a means for the prospective nurse to obtain knowledge related to the needs of the client. Ability skills are absolute as professional demands and competencies that must be achieved by a graduate. Clinical skills mastery is an important element of the professional 
Henny Yulianita : Cost Analysis of Nursing Practice by Applying Reuse and Repack Methods

quality of health education graduates, especially nursing (Suryadi, 2008).

Practical learning design strategy is the integration between the theory/knowledge and basic skills of professionals by using model approaches and learning methods, so that the implementation of learning is managed in an integrated manner. Practical learning provides opportunities for learners to develop skills and make accurate and regular observations (Nursalam \& Efendi, 2008). Learning practicum should pay attention to the management of tools and instruments as well as financing good activities. Financing analysis needs to be done to improve the efficiency of time and cost of learning activities of nursing practice.

\section{Limitations of the study}

This study only uses disinfection techniques for handling tools and materials that will be carried out by applying the reuse and repack methods. The current disinfection action is only able to reduce the risk of exposure to infection in repeated use of tools. To eliminate the risk of exposure to infection, it is better to handle the tools and materials using sterilization techniques. This sterilization technique is not carried out because of the limited tools and costs for sterilizing the devices. The management of good laboratory equipment and the availability of sterilizers are able to maintain sterile techniques on sterile practice tools and materials.

The use of reuse and repack methods on rubber tools and materials also has limitations in their use, considering that these rubber tools and materials will experience damage or wear due to repeated use. The use of reuse and repack methods on rubber tools and materials should be carried out 5 times up to 7 times the application of reuse and repack methods. There is a possibility that the tools and materials are damaged, such as torn, stretchy, leaking. Therefore, before forwarding the reuse and repack method, it is better to check and identify the state of the tool and material. Damaged tools and materials can affect the implementation of nursing action practices.

\section{Conclusion}

The result of cost analysis of nursing practice in laboratory using re-use technique and re-pack in urinary catheter curing obtained efficiency $94.92 \%$ and at installation of NGT obtained efficiency $97.90 \%$ compared to buying tool every doing practicum. This efficiency can reduce the burden of tuition fees borne by students.

Methods of re-pack and re-use is a wrapping method with the use of the sterile equipment used. It is expected that this method can lower the cost of practice and reduce environmental waste. Benefits of re-use methods: preventing pollution through waste reduction, energy saving, cost-effectiveness, reducing the amount of waste to be brought to the landfill, making the product usable for a long time and saving natural resources (Rose, 2017).

\section{References}

Asmadi. (2008). Konsep dasar keperawatan. Jakarta: EGC.

Detik News. (2013, November 9). Tehnik repacking dan sitostatika mampu menghemat obat hingga 8 miliar. Retrieved Februari 10, 2018, from: https://news.detik.com/ jawatimur/2408319/tehnik-repacking-dansitostatika-mampu-hemat-obat-hingga-rp-8miliar.

Hidayat, A.A. (2008). Pengantar konsep dasar keperawatan. Jakarta: Salemba Medika.

Kementerian Kesehatan Republik Indonesia. (2014). Pusat data dan informasi Kementerian Kesehatan RI tentang pendidikan tinggi kesehatan. Jakarta: Kementrian Kesehatan Republik Indonesia.

Kusnanto. (2004). Pengantar profesi dan praktik keperawatan profesional. Jakarta: EGC.

Nursalam., \& Efendi, F. (2008). Pendidikan 
Henny Yulianita : Cost Analysis of Nursing Practice by Applying Reuse and Repack Methods

dalam keperawatan. Jakarta: Salemba Medika.

Praptiningsih, S. (2006). Kedudukan hukum perawat dalam upaya pelayanan kesehatan di rumah sakit. Jakarta: PT.Raja Grafindo Persada.

Rose, K. (2017, April 25). What are benefits of reuse?. Retrieved February 10, 2018, from https://sciencing.com/benefits-reuse-4586. html.
Suryadi,E.(2008).Pendidikandilaboratorium keterampilan klinik. Yogyakarta: BPK UGM.

United States Environmental Protection Agency (EPA US). (2017, January 19). Reducing and reusing basics. Retrieved February 10, 2018, from https://www.epa. gov/recycle/reducing-and-reusing-basics.

Zainuddin, M. (2005). Pekerti mengajar di perguruan tinggi: Buku praktikum. Jakarta: PAU-PPAI Universitas Terbuka. 